specializes in conflict management, conflict analysis and conflict prevention.

Address: 2 Golf Course Dr., Mt Edgecombe 4302, South Africa. Website: http://www.accord.org.za

Executive Director: Vasu Gounden.

\section{American Enterprise Institute (for Public Policy Research)}

Founded 1943. Private, non-partisan think tank based around principles of private liberty, individual opportunity and free enterprise. Six principal research areas: economics; foreign and defence policy; health; legal and constitutional studies; political and public opinion studies; social and cultural studies.

Address: 1150 Seventeenth St., NW, Washington, D.C., 20036,

USA.

Website: http://www.aei.org

President: Arthur C. Brooks.

\section{Asian Development Bank Institute}

Founded 1997. Leading institute engaged in building capacity, skills and knowledge related to poverty reduction and other areas that support long-term growth and competitiveness in developing economies in the Asia-Pacific region. Research covers inclusive and sustainable growth, regional co-operation and integration, and governance for policies and institutions.

Address: Kasumigaseki Bldg 8F, 3-2-5 Kasumigaseki,

Chiyoda-ku, Tokyo 100-6008, Japan.

Website: http://www.adbi.org

President: Takehiko Nakao.

\section{Barcelona Centre for International Affairs (CIDOB)}

Founded 1973. Independent, non-partisan research centre that aims to become a point of reference in the field of international and development studies, generate ideas, undertake activities that increase awareness of belonging to a global community, and foster greater understanding of and between societies. Main thematic areas: security and development; globalization and regionalism; human rights and citizenship.

Address: C/ Elisabets 12, 08001 Barcelona, Spain.

Website: http://www.cidob.org

Director: Jordi Bacaria.

\section{Brookings Institution}

Founded 1916. Independent, frequently cited as the world's best think tank. Goals are to strengthen American democracy; foster the economic and social welfare, security and opportunity of all Americans; and secure a more open, safe, prosperous and cooperative international system. Priority research areas include energy and climate, growth through innovation, managing global change, and opportunity and wellbeing.

Address: 1775 Massachusetts Ave., NW, Washington, D.C., 20036, USA.

Website: http://www.brookings.edu

President: Strobe Talbott.

\section{Bruegel}

Founded 2004. Independent European think tank working in the field of international economics. Research areas: emerging powers and global governance structures; Europe's macroeconomic and structural challenges; competitiveness, innovation and financial regulation; climate change and energy.

Address: Rue de la Charité 33, B-1210 Brussels, Belgium.

Website: http://www.bruegel.org

Director: Guntram B. Wolff.

\section{Carnegie Endowment for International Peace}

Founded 1910. Independent think tank specializing in international affairs with particular focus on Russia and Eurasia, China, the Indian subcontinent/South Asia, globalization, nonproliferation and security affairs. Aims to advance co-operation between nations and promote active international engagement by the USA and become 'the first truly multinational-ultimately global-think tank'. Offices in Washington, D.C., Moscow, Beijing, Beirut and Brussels.

Address: 1779 Massachusetts Ave., NW, Washington, D.C., 20036-2103, USA.

Website: http://www.carnegieendowment.org

President: William J. Burns.

\section{Carnegie Middle East Center}

Founded in 2006 as part of the Carnegie Endowment for International Peace's Middle East programme. Public policy think tank and research centre that aims to better inform the process of political change in the Arab Middle East and deepen understanding of the complex security and economic issues that affect it. Programmes: Middle East economies; Arab politics; regional relations; security.

Address: Lazarieh Tower, Building No 2026 1210, Fifth Floor,

Emir Bechir St., Beirut, 11-1061 Riad El Solh, Lebanon.

Website: http://www.carnegie-mec.org

Director: Lina Khatib.

\section{Carnegie Moscow Center}

Founded in 1994 as a subdivision of the Carnegie Endowment for International Peace. Analyses the most important issues in international affairs and Russian domestic and foreign policy, as well as the regions they affect. Programmes: economic policy; foreign and security policy; non-proliferation; religion, society and security; Russian domestic politics and political institutions; society and regions.

Address: 16/2 Tverskaya, Moscow 125009, Russia.

Website: http://www.carnegie.ru

Director: Dmitry Trenin.

\section{Cato Institute}

Founded 1977. Non-profit public policy research foundation based on the principles of the American Revolution-limited government, free markets, individual liberty and peace. Comprises Centers for Constitutional Studies, Educational Freedom, Global Liberty and Prosperity, Representative Government and Trade Policy Studies.

Address: 1000 Massachusetts Ave., NW, Washington, D.C., 20001-5403, USA.

Website: http://www.cato.org

President: Peter N. Goettler.

\section{Center for a New American Security}

Founded 2007. Leading research institution engaged in developing strong, pragmatic and principled national security and defence 